\title{
The bioaerosols emitted from toilet and wastewater treatment plant: a literature review
}

\author{
Mengmeng Lou ${ }^{1} \cdot$ Shuai Liu ${ }^{1} \cdot$ Chunjie Gu ${ }^{1} \cdot$ Huimin $\mathrm{Hu}^{1} \cdot$ Zhengkun Tang $^{1} \cdot$ Yaopeng Zhang ${ }^{1} \cdot$ Chenye Xu $^{1,2}$. \\ Fang $\mathrm{Li}^{1,2}$
}

Received: 1 July 2020 / Accepted: 18 October 2020 / Published online: 24 October 2020

(C) Springer-Verlag GmbH Germany, part of Springer Nature 2020

\begin{abstract}
The aerosols harboring microorganisms and viruses released from the wastewater system into the air have greatly threatened the health and safety of human beings. The wastewater systems, including toilet and wastewater treatment plant (WWTP), are the major locations of epidemic infections due to the extensive sources of aerosols, as well as multifarious germs and microorganisms. Viruses and microorganisms may transport from both toilet and hospital into municipal pipes and subsequently into WWTP, which accounts for the main source of bioaerosols dispersed in the air of the wastewater system. This review aims to elaborate the generation, transmission, and diffusion processes of bioaerosols at toilet and WWTP. Moreover, the main factors affecting bioaerosol transmission and the corresponding prevention strategies for the airborne and inhaled bioaerosols are also discussed. Collectively, this review highlights the importance of managing bioaerosol occurrence in the wastewater system, which has aroused increasing concern from the public.
\end{abstract}

Keywords Bioaerosols $\cdot$ Toilet $\cdot$ Wastewater treatment plant $\cdot$ Airborne $\cdot$ Virus $\cdot$ Epidemic infections

\section{Introduction}

Recently, the infectious virus has infected over two million people all over the world (Holshue et al. 2020; Mohammadi et al. 2020; Xu et al. 2020). Infectious diseases have greatly threatened human health and economy over the last few decades, since infection may occur via various ways. Among them, airborne transmission is one of the most frequent ways, which posts a huge challenge for effective control (Lai et al. 2018; Nasir et al. 2016). Airborne transmission is defined as aerosol transmission (particle diameter, $<5 \mu \mathrm{m}$ ) or transmission at a distance of over $1 \mathrm{~m}$ (Fernstrom and Goldblatt 2013). Notably,

Responsible Editor: Diane Purchase

Chenye $\mathrm{Xu}$

xcy0714@dhu.edu.cn

$\triangle$ Fang Li

lifang@dhu.edu.cn

1 College of Environmental Science and Engineering, Donghua University, Shanghai 201620, China

2 State Environmental Science and Engineering Centre for Pollution Treatment and Control in Textile Industry, Shanghai 201620, China aerosol is capable of harboring germs and viruses while prolonging the retention time of such germs in the air due to its own stability (Knowlton et al. 2018). For human beings who are exposed in the air filled with inhalable bioaerosols colonized by viruses and microorganisms, the risk of severe infection may increase and various illnesses may be induced subsequently. It has been confirmed that human beings are easily infected by related bioaerosols generated mainly from two sites, namely, toilet and wastewater treatment plant (WWTP) (Fig. 1) (Barker and Bloomfield 2000; Heinonen-Tanski et al. 2009; Lin and Marr 2017; Xu et al. 2018).

Bioaerosols generated during toilet flushing were first reported by Jessen who detected the bacteria that seeded around the toilet after flushing (Johnson et al. 2013b). This experiment has thus aroused an increasing concern on the health and safety of toilet. Feces excreted from patients represents a major source of pathogenic bacteria in the toilet. Toilet flushing can partially reduce the bacterial concentration, but it also generates a mass of bioaerosols due to the turbulence and fluctuation of toilet water, which may increase the infection risk of toilet users because of the colonization by residual bacteria in the aerosol. A whole generation and airborne transmission process of pathogenic bioaerosols can be divided into three sections. For instance, Clostridioides difficile firstly shed from the 


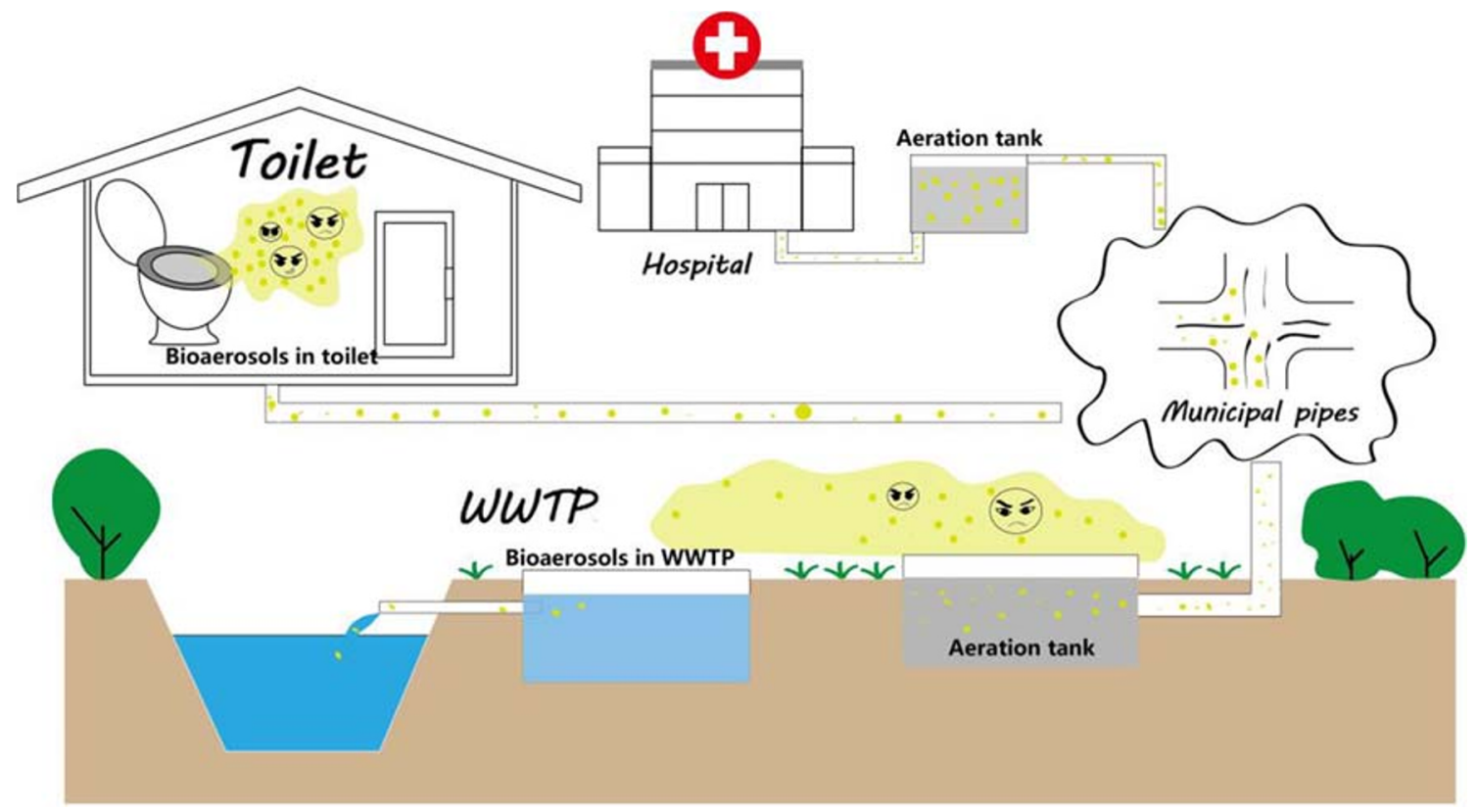

Fig. 1 Diagram of bioaerosols emitted from the wastewater system and the transport route of germs and viruses

gastrointestinal tract, and enters into the bowl of toilet by the excretion of feces. Toilet flushing with high velocity jet flow can atomize water droplet to produce bioaerosols, accompanied by the adsorption of Clostridioides difficile. The bioaerosols can be expelled from the air within the bowl of toilet depending on an upward velocity of air from flushing, and eventually be transmitted by air motion of indoor ( $\mathrm{Li}$ et al. 2020b; Wilson et al. 2020). In 2002, some flight attendants were infected with norovirus during the flight from London to Philippines because they used the toilet in the plane (Widdowson et al. 2005). The toilet has been the main site of germ and virus transmission as well as inhaled infection illnesses, and it is therefore important to understand the process and the influencing factors of toilet bioaerosols generation ( $\mathrm{Li}$ et al. 2020b).

WWTP is another hotspot associated with a high infection risk of bioaerosols. Compared with the bioaerosols of toilet, WWTP pathogenic bacteria enter into the receiving wastewater through municipal pipe. The main emission sources of bioaerosols include aeration tank, sludge dewatering room, and mechanical agitation (Karra and Katsivela 2007). The emitted bioaerosols have harbored bacteria and fungi, which can survive for weeks or even months in the water environment. Sewage workers exposed may thereby have increased infection risks (Grunwald et al. 2006). It was estimated, there was $10^{5}-$ $10^{11}$ enteric viral particles per gram stool excreted from an infected person with diarrhea, which ultimately made some contributions to WWTP bioaerosols. Those enteric viral particles can be adsorbed by small droplet bubbles (Moazeni et al. 2017; Pasalari et al. 2019). As these mixed droplet bubbles reach to the tank surface, they can immediately burst to generate aerosolized fine droplets carrying enteric virus, spread into the atmosphere (Mirskaya and Agranovski 2018). The illness among sewage workers, which is named "sewage worker's syndrome," has been reported (Zabinski et al. 2018). The risk of exposure for sewage workers is associated with the characteristics of bioaerosols that vary depending on the climate, the types of WWTP and wastewater, and the aeration methods (Han et al. 2019; Zhang et al. 2020). Infection with bioaerosols can result in respiratory and cardiovascular diseases. Generally, the microorganism concentration, size distribution, and microbial population of bioaerosols are the important characteristics related to human health. Therefore, bioaerosols have become an increasing health risk in WWTP, and more and more studies have been reported aiming to assess the risk of exposure and determine the control for bioaerosols (Benami et al. 2016a; Haas et al. 2017; Uhrbrand et al. 2017).

To date, few reviews have focused on the bioaerosols from both toilet and WWTP simultaneously. In light of the recent outbreak of infectious diseases, the existence of airborne bioaerosols can no longer be ignored. Thus, it is urgent to review the risk assessment and management strategies of bioaerosols. This review summarizes the sources of bioaerosols from toilets and WWTP, illustrates the influencing factors for bioaerosol generation and transmission, and discusses the corresponding recommendations and control strategies for safe sanitation management.

\section{Toilet bioaerosols}

\section{Generation of toilet bioaerosols}

Toilet flushing may contribute to the release of bioaerosols that persist in the indoor environment of toilet (Verani et al. 
2014). The factors affecting bioaerosol generation during the toilet flushing involves multiple interactions between liquid and air, the ways of flushing, and the structures of toilet. Specifically, the flushing is initiated by triggering the flashing valve. At that time, a portion of water enters into the bowl of toilet along its wall while the others splash into the bowl with a high flow velocity. The siphon phenomenon occurs within a few seconds. This process results to the formation of fine droplet or droplet film combined with bacteria due to drastic turbulence, and subsequently aerosolized by bursting at the air-liquid interface. In addition, siphon phenomenon also gives rise to the pressure and weight of mixed liquid increasing. The splashing liquid washes the wall of bowl that results to the formation of vortices near the wall. The vortices move continuously upward under the action of the inertia force, which driving an upward airflow vortex within the bowl of toilet (Fig. 2). Such upward airflow vortex can expel bioaerosols from bowl to air above the toilet, and thus accelerate the spreading of bioaerosols ( $\mathrm{Li}$ et al. 2020b). In the 1950 s, Jessen et al. firstly proposed the concept that toilet flushing might lead to the generation of bioaerosols (Johnson et al. 2013b). In that study, Serratia marcescens was concentrated into the toilet before flushing; meanwhile, the sedimentation plates were placed around the toilet at different distances to collect the settled bioaerosols. Their results showed that the bacterial colonies grew onto the sedimentation plates placed on the ground. Such observation forcefully demonstrated that bacteria and microorganisms might be carried by the fine liquid drops and settled onto the toilet surface. Moreover, microorganisms were also detected in the air,

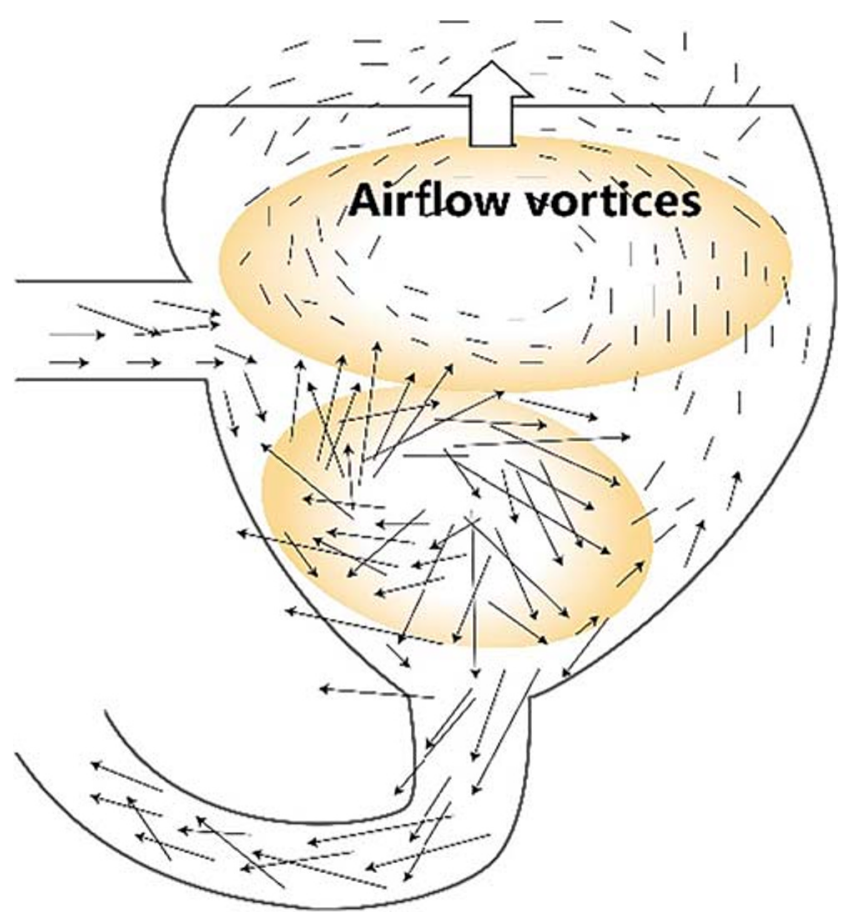

Fig. 2 The formation of airflow vortices in the toilet bowl during flushing indicating that aerosols might assist in the prolonged retention time of microorganisms in the air. Similarly, Darlow et al. planted bacteria into the toilet using an s-shaped outlet sink, and sampled the air above the toilet using a liquid impactor and a Bourdillon impactor (Darlow and Bale 1959). Their results indicated that bioaerosols were detected in the collected samples at 5-7 min after flushing. The abovementioned experiments suggest that toilet flushing is the main cause of bioaerosol generation. As presented in Table 1, most studies are conducted by culturing various bacteria and counting.

Infections on the account of airborne transmission of bioaerosols may easily occur, because there is a large proportion of immunocompromised patients in hospital. Besides, the nosocomial toilets have been increasingly recognized as the important sources of bioaerosol generation. For instance, Knowlton et al. first measured the concentrations of particulate matter (PM) and bioaerosols in the hospital toilets under three different conditions (Knowlton et al. 2018), including no waste no flushing, no waste with flushing, and fecal waste with flushing. Moreover, the concentrations of particles and bioaerosols were measured by a particle counter bioaerosol sampler at the distances of $0.15,0.50$, and $1 \mathrm{~m}$ from the toilet for 5, 10, $15 \mathrm{~min}$ before and after a toilet flushing behavior. As discovered when compared the particle and bioaerosol concentrations among these three conditions, the concentrations of both were significantly changed before and after feces flushing. To be specific, the bioaerosol concentrations in the case of feces flushing were greater than the background concentrations. Furthermore, there was no difference in bioaerosol concentration at different time points, suggesting that bioaerosols were able to stay in the air for a long time. Their study highlighted that waste and flushing in hospital toilets contributed to increasing the bioaerosol concentrations.

Further, Aithinne et al. conducted an experiment to investigate the persistence of $C$ difficile spores on the contaminated surfaces close to and away from the toilet (Aithinne et al. 2019). First of all, $C$ difficile spores were seeded into the toilet with a flushometer, and then bowl water samples were periodically collected and plates were settled after flushing. Later, the plate impactors were rotated to sample the air after each flushing. Their results proved that the toilet contaminated by $C$ difficile spores was difficult to clean even after flushing for over 24 times, and the action of toilet flushing might augment the risks of bioaerosol generation and airborne transmission.

\section{Toilet bioaerosols pose a threat to health}

Pathogenic bacteria at high concentrations are mainly found in the vomit and feces of patients, which can then transfer into the toilet. Bioaerosols contain bacteria produced by toilet flushing, suggesting that toilet can serve as the transmission medium of pathogenic bacteria. The persistent contamination by bacteria colonizing the surface and bowl of toilet increases 
Table 1 Bioaerosol concentrations from toilet flushing

\begin{tabular}{|c|c|c|c|c|}
\hline Microorganism/inoculum & Technique & Total droplets produced & Bioaerosol concentrations & Reference \\
\hline Staphylococcus epidermidis & Andersen sampler, Culture & $\begin{array}{l}2.40-3.20 \times 10^{5} \\
1-1.70 \times 10^{4}\end{array}$ & $\begin{array}{l}270 \mathrm{CFU} / 10^{9} \text { bacteria input } \\
40 \mathrm{CFU} / 10^{9} \text { bacteria input }\end{array}$ & (Knowlton et al. 2018) \\
\hline $\begin{array}{l}\text { MS2 } \\
\text { Phi6 }\end{array}$ & $\begin{array}{l}\text { Scanning mobility particle sizer, } \\
\text { aerodynamic particle size } \\
\text { spectrometer, culture }\end{array}$ & $1.50-2.50 \times 10^{6}$ & $\begin{array}{l}20 \mathrm{PFU} / \mathrm{L} \\
0.10 \mathrm{PFU} / \mathrm{L}\end{array}$ & (Lin and Marr 2017) \\
\hline $\begin{array}{l}\text { Fluorescent polymer } \\
\text { microspheres }\end{array}$ & $\begin{array}{l}\text { Grimm aerosol spectrometer, } \\
\text { fluorescence microscope }\end{array}$ & $\begin{array}{l}10,620 \\
145,214\end{array}$ & $\begin{array}{l}235 \text { droplet nuclei } / \mathrm{m}^{3} \\
513 \text { droplet nuclei } / \mathrm{m}^{3}\end{array}$ & (Johnson et al. 2013a) \\
\hline Total bacteria & Culture & - & $>100 \mathrm{CFU} / \mathrm{m}^{3}$ & (Verani et al. 2014) \\
\hline C difficile spores & Culture & - & $<100 \mathrm{CFU} / \mathrm{m}^{3}$ & (Aithinne et al. 2019) \\
\hline
\end{tabular}

the infection risk of toilet users. As a result, sanitation personnel and toilet users may inhale the contaminated aerosols into their lungs or touch the microbiologically contaminated surfaces, thereby inducing inhaled and contact infections (Bennett et al. 1999; Darquenne et al. 1997). Even though toilets are strictly cleaned on a daily basis, pathogenic bacteria and microorganisms can still be found (Giannini et al. 2009). Most pathogenic bacteria, including Shigella, E. coli, Clostridium difficile, severe acute respiratory syndrome (SARS), coronavirus, and norovirus, can survive on the toilet surface for weeks or even months (Kramer et al. 2006). In the 1950s, Hutchinson first reported the impact of toilet bioaerosols on disease transmission, and found that Shigella bacteria lingered on toilet seats, which possibly caused the spread of diarrhea (Hutchinson 1956). Since then, many researchers have conducted relevant studies to examine the influences of toilet bioaerosols on public health. The hazards and transmission routes of residual microorganisms after flushing are displayed in Table 2.

Gerba et al. investigated the hazard of bioaerosols in domestic toilets (Gerba et al. 1975). In brief, E. coli and poliovirus were seeded into the toilets, and later, agar plates were placed to collect bacteria and viruses dropping from aerosols in the surrounding air. As a result, lots of bacteria and viruses were not only left in the toilet after flushing but were also detected on the bathroom surfaces. This might be explained by the fact that aerosols containing bacteria and viruses were transmitted through the airborne way in the air, which eventually settled down onto the entire bathroom surface where people might contact with those bacteria.

Bioaerosols are more likely to transmit pathogenic microorganisms from person to person by the moving air during the diarrhea of patients. For example, Barker et al. seeded the Salmonella suspension into the toilet bowl at a concentration of $10^{8} \mathrm{CFU} / \mathrm{mL}$, so as to mimic the environmental conditions associated with acute diarrhea (Barker and Bloomfield 2000). After inoculation, the concentration of Salmonella in the toilet bowl was about $10^{4}-10^{5} \mathrm{CFU} / \mathrm{mL}$, which reduced to $10-40$ $\mathrm{CFU} / \mathrm{mL}$ after flushing. Although the flushing behavior effectively decreased Salmonella concentration in the blow of toilet, it also resulted in the contamination of the toilet seat, toilet seat lid, and toilet air (Table 3). This suggested that toilet flushing might contaminate toilet seat, toilet lid, and the surroundings of toilet during the event of diarrhea; meanwhile, it also led to airborne transmission of the contaminated bathroom surfaces (Table 3). Therefore, the pathogens of gastrointestinal tract infection may be transmitted to other family members through toilet bioaerosols during the diarrhea of a patient, which results in considerable health risk.

In 2002, norovirus outbroke in the USA, which was mainly attributed to the environmental pollution (Widdowson et al. 2004). The cleansing process was complicated due to the resistance of norovirus to the common disinfectants and the lack of alternatives to disinfectant compounds. Carling et al.

Table 2 Microbial residues and transmission routes in toilet after flushing

\begin{tabular}{|c|c|c|c|c|c|}
\hline \multirow[t]{2}{*}{ Types of bacteria } & \multicolumn{2}{|c|}{ Bacteria counts/concentrations } & \multirow[t]{2}{*}{ Hazard/disease } & \multirow[t]{2}{*}{ Pathway } & \multirow[t]{2}{*}{ References } \\
\hline & Toilet & bathroom & & & \\
\hline Poliovirus & 2802 & 737 & Poliomyelitis & Contact & (Gerba et al. 1975) \\
\hline E.coli bacteriophage $M S-2$ & 137,000 & 35,468 & Diarrhea & Contact & \\
\hline Salmonella & - & - & Diarrhea & Inhalation & (Barker and Bloomfield 2000) \\
\hline MS2 bacteriophage & $2420 \mathrm{PFU} / \mathrm{m}^{3}$ & - & Diarrhea & Contact & (Barker and Jones 2005) \\
\hline Serratia & $1370 \mathrm{CFU} / \mathrm{m}^{3}$ & - & Diarrhea & Contact & \\
\hline E.coli bacteriophage MS-2 & $10^{3} \mathrm{PFU} / \mathrm{cm}^{3}$ & - & Diarrhea & Contact & (Sassi et al. 2018) \\
\hline
\end{tabular}


Table 3 Position and concentration of residual bacteria in the toilet after flushing

\begin{tabular}{lll}
\hline Sites & Bacterial concentrations & References \\
\hline Walls & 5 PFU & (Gerba et al. 1975) \\
Floor & $>100 \mathrm{PFU}$ & \\
Seat, toilet & $15 \mathrm{PFU}$ & \\
Rim, toilet & $>60 \mathrm{PFU}$ & \\
Flush handle & $2 \mathrm{PFU}$ & \\
Bathtubs, sinks, & $>100 \mathrm{PFU}$ & \\
Toilet bowl water & $40 \mathrm{CFU} / \mathrm{mL}$ & \\
Toilet seat (top) & $0.17 \mathrm{CFU} / \mathrm{cm}^{2}$ & \\
Toilet seat (underside) & $6 \mathrm{CFU} / \mathrm{cm}^{2}$ & (Barker and Bloomfield 2000) \\
Toilet bowl surface & $5 \times 10^{7} \mathrm{CFU} / \mathrm{mL}$ & \\
Toilet bowl water & $2 \times 10^{8} \mathrm{CFU} / \mathrm{mL}$ & \\
Flush handle & $1.65 \pm 0.91 \mathrm{PFU} / \mathrm{cm}^{2}$ & \\
Toilet back & $2.89 \pm 1.04 \mathrm{PFU} / \mathrm{cm}^{2}$ & \\
Back wall & $1.63 \pm 1.36 \mathrm{PFU} / \mathrm{cm}^{2}$ & \\
Floor & $3.44 \pm 1.08 \mathrm{PFU} / \mathrm{cm}^{2}$ & \\
Toilet paper dispenser & $1.49 \pm 1.41 \mathrm{PFU} / \mathrm{cm}^{2}$ & \\
Toilet bowl rim & $3.88 \pm 1.59 \mathrm{PFU} / \mathrm{cm}^{2}$ & \\
Toilet seat top & $4.21 \pm 1.26 \mathrm{PFU} / \mathrm{cm}^{2}$ & \\
Toilet seat underside & $4.22 \pm 1.26 \mathrm{PFU} / \mathrm{cm}^{2}$ & \\
\hline
\end{tabular}

discovered that cruise passengers were susceptible to infection, and they also evaluated the thoroughness of disinfection cleaning (TDC) of public toilets among the 56 large cruise ships (Carling et al. 2009). According to their results, only a few of those ships were satisfactory in terms of cleanliness, while most had a TDC score of less than $30 \%$. Besides, three of those 56 cruise ships surveyed experienced norovirus outbreaks. An assessment of the TDC scores during the first 4 months of outbreak revealed that the average TDC score of the three ships $(10.3 \%)$ was significantly lower than that of the 40 ships not experiencing norovirus. Typically, a lower TDC score indicated that norovirus was more likely to spread on cruise ships during diarrhea. Furthermore, Barker et al. added the semi-solid agar containing Serratia and MS2 bacteriophages into the toilet to mimic acute diarrhea, and compared the numbers of Serratia attached onto the toilet surface before and after flushing (Barker and Jones 2005). Their experiments indicated that one single flushing reduced the amount of bacteria in the toilet, but there were still plenty of bacteria on the toilet surface and in the toilet blow water. These bacteria further emitted into the surrounding air by the next flushing. Thirty minutes after toilet flushing, the surface contamination was detected at different locations around the toilet. Such situation might cause continuous airborne diffusion and the transfer of infection from hand to mouth.

The seat, lid, surrounding floor, and surrounding surface of toilet were contaminated with bioaerosols after toilet flushing. Sassi et al. added Escherichia coli bacteriophage MS2 into the toilet bowl to assess the degree of bioaerosol contamination on the toilet surface after flushing (Sassi et al. 2018). Their results proved the presence of phages on both the upper and lower sides of toilet seats. Moreover, Mendes and Lynch seeded 130 toilets in the public areas (including shops, offices, factories, railway sites, schools, and hospitals) to examine the microbial populations at suspectable locations in male and female toilets (Mendes and Lynch 1976). Their results declared that the toilet surfaces, including wash basin, toilet seat, faucet handle, the floor around the toilet, and toilet water, might be contaminated by bioaerosols. Among them, the wash basin, toilet seat, faucet handle, and the inside handle of the entry door were highly contaminated, whereas some surfaces (such as cabinet door lock and handle) were rarely contaminated. This phenomenon was possibly explained by the fact that the surfaces of door lock and handle were usually too dry for the bacteria to survive. By contrast, the wash basin, the handles inside the entrance door, and the faucet were usually touched after washing hands; thus, the moisture in the hands might benefit bacterial survival. Barker et al. also discovered that Salmonella was not detected in the dry places, since Salmonella mostly existed in the wet places (Barker and Bloomfield 2000). Therefore, dry surface was the key factor that affected the survival of Salmonella. Such surfaces contaminated with bioaerosols might facilitate the cross-infection of body and hands, thus increasing the risk of disease transmission.

\section{Influencing factors of toilet bioaerosols}

The atomized droplets from the toilet blow water are regarded as the precursor of bioaerosols (Lange and Finlay 2006). 
According to the existing studies, atomized droplets are associated with three aspects, namely, the types of toilets, opening and closing of toilet lid, and the energy of flushing. The bioaerosol concentrations under different conditions are exhibited in Table 4.

\section{Types of toilets}

Different types of toilets may generate bioaerosols at different concentrations during toilet flushing. Of them, the straight toilet flushing converts the gravity of water into the force of water, thereby directly flushing out the excrement. In comparison, the siphon type toilet is assembled by an S-shaped pipe, which relies on the atmospheric pressure to push liquid from the high place down to the lower place through the siphon, so as to form a whirlpool that is conducive to the removal of contaminants. Bound and Atkinson conducted experiments on the two types of toilets, namely, direct flush and the siphon type (Bound and Atkinson 1966). As shown by the results in Table 4 , the siphon toilet produced only $1 / 14$ as many bioaerosols as those of direct flush toilet flushed with the same amount of water. This further confirmed that the types of toilets significantly affected bioaerosol concentrations.

\section{Opening and closing of toilet lid}

The distinguishable air turbulence can be caused when the toilet is flushed with or without lid closing, thus resulting in the airborne transmission of bioaerosols that contaminate different sites of the toilet. Notably, flushing the toilet without closing the lid will lead to severe surface contamination of the toilet (Barker and Bloomfield 2000; Barker and Jones 2005; Bound and Atkinson 1966). To take an example, Best et al. inoculated $C$. difficile into the toilet bowl water, and measured the bacterial concentrations and aerosolization when the lid was opened and closed, respectively (Best et al. 2012). Their results showed that $C$. difficile was detected at the height of $25 \mathrm{~cm}$ above the toilet bowl within $90 \mathrm{~min}$ when a lidless toilet was flushed, while the bacterial concentration of the closed lid was 12 times lower than that of the lidless toilet (Table 4). Flushing the lidless toilet distinctly increased the risk of immediate contamination with $C$. difficile. Typically, toilets with lid seem to be a straightforward strategy for reducing the related airborne transmission of bioaerosols.

\section{Flushing energy}

Varying flushing energies may result in distinct concentrations and sizes of bioaerosols, which in turn affect bacterial emission. For example, Lai et al. conducted an experiment using the two most popular flushing systems (namely, the flushometer and cistern systems) at two different water pressures $(400 \mathrm{kPa}$ and $200 \mathrm{kPa})$ and tank heights $(46 \mathrm{~cm}$ and 95 $\mathrm{cm}$ ) (Lai et al. 2018). Then, three different types of bacteria representing large, medium, and small pathogens were tested at two different water pressures and two tank heights, respectively. Afterwards, the correlations of the release of pathogenic bacteria by toilet flushing with the droplet concentration and bacterial size were examined. Their results illustrated that the bioaerosol concentration generated by the flushometer system was significantly higher than that of the cistern system (Table 4). This might be attributed to the fact that the tank pressure was only $5 \%$ of the flusher pressure, and the droplets of the tank system had much less atomizing energy. They also discovered that the bioaerosol concentrations were positively correlated with pathogen concentrations under HP, LP, and HT conditions. Thus, it was clear that the higher energy of flushing enabled to produce the higher concentration of pathogen aerosols; meanwhile, a cistern tank design was superior to a flushometer design with regard to bioaerosol generation.

Johnson et al. evaluated bioaerosol emissions from toilet flushing of the high efficiency, pressure-assisted high

Table 4 Bioaerosol concentration generated by toilet flushing under different conditions

\begin{tabular}{llll}
\hline Influencing factors & Conditions & Bioaerosol concentrations & Reference \\
\hline Toilet types & Straight flush & 37.50 colonies/100 cft & (Bound and Atkinson 1966) \\
& Siphon type & 2.60 colonies/100 cft & (Best et al. 2012) \\
Switch toilet lid & Open & $35 \mathrm{CFU}$ & \\
& Closed & $3 \mathrm{CFU}$ & (Lai et al. 2018) \\
Flushing energy & High pressure (HP) & $287,400 \pm 32,700$ droplets & \\
& Low pressure (LP) & $80,200 \pm 6900$ droplets & (Johnson et al. 2013a) \\
& High water tank (HT) & $13,700 \pm 3000$ droplets & $14,500 \pm 2100$ droplets \\
& Low water tank (LT) & 10,620 droplets & 25,762 droplets \\
\end{tabular}


efficiency (PAT), and flushometer (FOM) toilets using similar bowl water and flush volumes (Johnson et al. 2013a). Among those toilets, the FOM toilet generated the most bioaerosol droplets, and the high-energy flushometer produced over three times as many bioaerosol droplets as those of the lower energy PAT (Table 4), which was consistent with the experimental results from Lai (Lai et al. 2018). Moreover, Newsom et al. added feces containing bacterial suspensions into the high and low cisterns, respectively, and the identical results demonstrated that the higher flushing energy resulted in the higher bioaerosol concentration (Newsom 1972). The above experiments provide additional support for the concerns that the energy of flushing may affect the droplet nuclei bioaerosols, which is thus correlated with the airborne transmission of infectious disease.

\section{Bioaerosols in the process of wastewater treatment}

\section{The sources of bioaerosols from WWTP}

Microorganisms and viruses in wastewater can be aerosolized by bubble bursting, mechanical motion, and water turbulence. They are able to result in the generation of bioaerosols. The bubbles reach the gas-liquid interface, burst, and are ejected up to a certain height above the surface (Lv et al. 2020; Montoya et al. 2017). Thereafter, a small portion of film drops into the surrounding air along with microorganisms in the form of bioaerosols. Therefore, WWTP can be a hazardous location for WWTP workers and the surrounding residents (Benami et al. 2016b). The microorganisms derived from wastewater can easily escape into the surrounding air by the airborne transmission of bioaerosols, which is ascribed to the intensive mechanical motion. Mechanical agitation, aeration, and sludge dewatering in the process of WWTP also contribute to the release of microorganisms and bacteria. In addition, varying types of germs can be observed during different treatment processes because of the distinct performances of wastewater (Uhrbrand et al. 2017). The bioaerosol concentrations in different treatment sections of WWTP are summarized in Table 5.

Non-negligible bacterial emissions occurred in the coarse screen and the primary settling tank, which declared the high risk of infection when exposed in the pretreatment process, even though in the absence of aeration and sludge (Zhang et al. 2018). Typically, the pristine bacteria in the influent of wastewater are the main sources of bioaerosols. Furthermore, the rotation of grid machine and aeration of biochemical pool also facilitate the generation of atomized droplets, which form bioaerosols along with the microorganisms and are subsequently emitted into the air of WWTP. Consequently, the bacterial numbers in the aeration tank were much higher than those during the pretreatment process (Table 5). Moreover, when the sludge moisture content is reduced to within the sludge disposal requirements by the filter press, the microorganisms contained in the sludge can easily escape into the air during this process. More seriously, sludge dewatering facilities are generally installed indoors, which facilitates bioaerosol accumulation in the air of sludge dewatering room due to the relatively closed space and poor ventilation (Amha et al. 2017). To sum up, the coarse grid, aeration sedimentation tank, biochemical tank, and sludge dewatering room represent the major sources of bioaerosols within WWTP.

\section{The hazards of bioaerosols of WWTP}

\section{The characteristics of bioaerosols of WWTP}

The toxicity of bioaerosols is closely related to their concentrations, particle size distributions, and compositions. Proliferation occurs after bioaerosols entering the human body

Table 5 Bioaerosol concentrations in different process sections of WWTP. Units: CFU $/ \mathrm{m}^{3}$

\begin{tabular}{|c|c|c|c|c|c|c|}
\hline Different process sections & $\begin{array}{l}\text { Coarse screen } \\
\mathrm{CFU} / \mathrm{m}^{3}\end{array}$ & $\begin{array}{l}\text { Primary settling } \\
\text { tanks }\end{array}$ & Aeration tanks & $\begin{array}{l}\text { Secondary } \\
\text { settling tanks }\end{array}$ & $\begin{array}{l}\text { Sludge } \\
\text { dewatering room }\end{array}$ & References \\
\hline Total bacterial count & 1988 & 2800 & 4726 & - & 5565 & \multirow[t]{2}{*}{ (Li et al. 2011) } \\
\hline Total fungal count & 212 & 1,590 & 583 & - & 830 & \\
\hline Total bacterial count & 80 & - & 2005 & - & 3,807 & \multirow[t]{4}{*}{ (Yang et al. 2019b) } \\
\hline Total fungal count & 255 & - & 678 & - & 1,254 & \\
\hline Staphylococcus & 70 & - & 141 & - & 283 & \\
\hline Pseudomonas aeruginosa & 5 & - & 9 & - & 22 & \\
\hline Total bacterial count & 469 & 289 & 684 & 49 & 69 & \multirow{2}{*}{$\begin{array}{l}\text { (Malakootian et al. 2013) } \\
\text { (Yang et al. 2019a) }\end{array}$} \\
\hline Total bacterial count & 2144 & 2093 & 4878 & 60 & 74 & \\
\hline Total bacterial count & 749 & 575 & 1373 & 296 & 944 & \multirow[t]{2}{*}{ (Fathi. et al. 2017) } \\
\hline Total fungal count & 720 & 985 & 1384 & 388 & 497 & \\
\hline
\end{tabular}


(Haas et al. 2017). Particulates less than $10 \mu \mathrm{m}$ in diameter are referred to the respirable particulates (PM 10 and PM 2.5); they tend to reach into the lungs and blood via the respiratory tract, causing severe lung diseases (Gorny 2020). Bioaerosols with a size range of $0.03-4 \mu \mathrm{m}$ can be formed by the aggregation of bacterial and fungal species (Hsiao et al. 2020; Li et al. 2011). These smaller particles are able to enter the deeper parts of human body that cause higher risks to human body.

The bioaerosols of WWTP contain various pathogenic and non-pathogenic substances dispersed in the air (Liu et al. 2020). Most bacteria, fungi, and viruses can be detected in bioaerosols of WWTP (Han et al. 2019; Li et al. 2020a; Uhrbrand et al. 2017). Additionally, chemicals such as $\mathrm{Cl}^{-}$, $\mathrm{NH}^{4+}, \mathrm{Ca}^{2+}$, as well as carcinogenic substance (As, $\mathrm{Cd}$, and Co) also existed from bioaerosols (Han et al. 2020a; Yang et al. 2019b).

\section{The potential risks of bioaerosols}

Inhalation and direct contact are the two principal pathways that lead to bioaerosol-induced disease occurrence (Table 6). It is reported that the incidences of respiratory and intestinal diseases increase among the WWTP employees, which may be ascribed to the exposure to bioaerosols (Benami et al. 2016a; Heinonen-Tanski et al. 2009; Li et al. 2016). Additionally, the microorganism types play an important role in affecting the health of WWTP workers and the residents nearby (Table 6). Different types of microorganisms emitted during the wastewater treatment processes are listed in Table 6, which can lead to various hazards and diseases. Furthermore, the emerging contaminants, which contain the bacteria resistant to antibiotics (such as erythromycin- $\mathrm{H}_{2} \mathrm{O}$ ), methamphetamine, and ketamine, have been detected in WWTP, thereby enriching the types of bioaerosols (Caucci et al. 2016; Hsiao et al. 2020). Although the concentrations of those emerging contaminants in the air of WWTP are much lower than those in the wastewater, the corresponding values are comparable to those of liquid when converted to a perairborne PM basis (Hsiao et al. 2020). The airborne transmission of bioaerosols is mainly ascribed to the gas-liquid exchange and gas-gas exchange at the air-wastewater interface. Noteworthily, the transmission displays the three-dimensional characteristics and is also affected by the environmental factors (Bauer et al. 2002).

\section{Influencing factors of bioaerosols}

The aeration systems, treatment sections, and natural conditions may affect the different specialties of bioaerosols. Firstly, the aeration systems are supported by two drivers of aeration and mechanical agitation, which result to the distinguishing driving force and flow state of liquid. Because the bacteria are susceptible to external conditions, natural conditions of solar radiation, wind speed, rainfall, relative humidity, and temperature affect the characteristics and concentrations of bioaerosols in WWTP. A few examples of bioaerosol concentrations under different conditions in WWTP are presented in Table 7.

\section{Aeration methods}

Splashing and bubble bursting occur in aeration system as a result of forced aeration in activated sludge processes, which produce large amount of bioaerosols (Fracchia et al. 2006). Various bubble sizes govern by different types of aeration greatly affect the number of airborne microorganisms. MA et al. monitored six different WWTP to determine the main source of bioaerosols and to evaluate the influences of diverse biological treatment aeration systems (air diffusion, horizontal rotors, and surface turbine aerators) on the exposure to air microbial levels (Sanchez-Monedero et al. 2008). In this study, the aeration systems of different wastewater mechanical

Table 6 Concentrations and hazards of bioaerosols at different sites in WWTP

\begin{tabular}{|c|c|c|c|c|c|}
\hline Sites & $\begin{array}{l}\text { Bioaerosol } \\
\text { concentrations } \\
\left(\mathrm{CFU} / \mathrm{m}^{3}\right)\end{array}$ & Bacteria/microorganism & Pathway & Hazard/diseases & References \\
\hline Coarse screen & 2200 & Penicillium, Aspergillus, Candida & Inhalation & High carcinogenic & (Li et al. 2011) \\
\hline $\begin{array}{l}\text { Primary settling } \\
\text { tanks }\end{array}$ & 2093 & $\begin{array}{l}\text { Micrococcus, Bacteroides, } \\
\quad \text { Pseudomonas, Acinetobacter }\end{array}$ & $\begin{array}{l}\text { Inhalation, } \\
\text { skin contact }\end{array}$ & $\begin{array}{l}\text { Allergic reactions, } \\
\text { toxic responses }\end{array}$ & (Yang et al. 2019a) \\
\hline Aeration tanks & 2833 & $\begin{array}{l}\text { Fecal coliforms, Staphylococcus, } \\
\text { Pseudomonas aeruginosa }\end{array}$ & Inhalation & High carcinogenic & (Karra and Katsivela 2007) \\
\hline $\begin{array}{l}\text { Secondary } \\
\text { settling tanks }\end{array}$ & 1537 & $\begin{array}{l}\text { Total coliforms, fecal coliforms, } \\
\text { fecal streptococci }\end{array}$ & Inhalation & $\begin{array}{l}\text { Fatigue, dizziness, eye } \\
\text { irritation, and } \\
\text { abdominal pain }\end{array}$ & (Malakootian et al. 2013) \\
\hline $\begin{array}{l}\text { Sludge } \\
\text { dewatering } \\
\text { room }\end{array}$ & 6395 & $\begin{array}{l}\text { Enterobacteriaceae, } \\
\text { Staphylococcus aureus, } \\
\text { Pseudomonas aeruginosa }\end{array}$ & Inhalation & High carcinogenic & (Yang et al. 2019b) \\
\hline
\end{tabular}


Table 7 Bioaerosol concentrations in WWTP in the presence of different environmental influencing factors

\begin{tabular}{|c|c|c|c|c|c|}
\hline Influencing factors & $\begin{array}{l}\text { Total } \\
\text { bacterial } \\
\text { count }\end{array}$ & $\begin{array}{l}\text { Total } \\
\text { fungal } \\
\text { count }\end{array}$ & Staphylococci & $\begin{array}{l}\text { Total } \\
\text { coliforms }\end{array}$ & References \\
\hline Mechanical agitation & 483.30 & 541.60 & 25.90 & 75.20 & \multirow{2}{*}{$\begin{array}{l}\text { (Brandi et al. } \\
2000)\end{array}$} \\
\hline $\begin{array}{l}\text { Bubble diffused air } \\
\text { system }\end{array}$ & 11.10 & 38.80 & 20.80 & - & \\
\hline Winter & 904 & 781 & - & - & \multirow[t]{2}{*}{ (Niazi et al. 2015) } \\
\hline Summer & 1882 & 1063 & - & - & \\
\hline spring & 1857 & 1553 & - & - & \multirow[t]{2}{*}{ (Fathi et al. 2017) } \\
\hline Summer & 889 & 1215 & - & - & \\
\hline Rainy season & $400-2800$ & $840-4520$ & - & - & \multirow[t]{3}{*}{ (Park et al. 2017) } \\
\hline Dry & $100-200$ & $240-380$ & - & - & \\
\hline season & & & & & \\
\hline
\end{tabular}

Units: CFU $/ \mathrm{m}^{3}$ agitations were compared to each other. The results indicated that the amount of bioaerosols $\left(450-4,580 \mathrm{CFU} / \mathrm{m}^{3}\right)$ generated from the horizontal rotor and surface turbine was much greater than that of the diffuser aerator $\left(22-57 \mathrm{CFU} / \mathrm{m}^{3}\right)$. Additionally, the amount of bacteria produced by the air diffuser was quite similar to that registered in the background location $\left(<50 \mathrm{CFU} / \mathrm{m}^{3}\right)$, and it was not affected by the activities in WWTP. The impacts of aeration systems on the release of bioaerosols followed the order of air diffuser $<$ surface turbine $<$ horizontal rotor. Besides, using the air diffuser as a biological treatment aeration system can greatly reduce the potential biological hazards.

Han et al. selected the same wastewater treatment plants as the objects of study to investigate the wastewater discharge, particle size distribution, microorganisms, and chemical composition by horizontal rotor aeration and fine bubble aeration (Han et al. 2020b). Compared with fine bubble aeration, horizontal rotor aeration generated a more coarse fraction $(>7 \mu \mathrm{m}$ in size) and a comparable inhalable part $(<3.30 \mu \mathrm{m}$ in size $)$. Moreover, numerous types of potential pathogens were generated by horizontal rotor aeration. Trichosporon and Mycobacterium, the most easily aerosolized genera, were generated by horizontal rotor aeration and fine bubble aeration, with the corresponding relevant bioaerosol factors of 633.70 and 192.56, respectively. This can be explained by the fact that horizontal rotor aeration is able to absorb part of the air into the rear side by the negative pressure zone based on the rotation of the horizontal rotors. This phenomenon causes water jump and vigorous stirring at the liquid level, and thus facilitated the aerosolization of microorganisms.

Han et al. also investigated the characteristics of submicron bioaerosols generated from the aeration system (Han et al. 2019). In their study, a laboratory simulation bioaerosol generator was employed to generate bioaerosols. They analyzed key characteristics of bioaerosols including the particle number size distributions, bioaerosol liquid water content, and chemical and microbial compositions. In conclusion, the size distributions of submicron bioaerosols ranged from 68 to 350 $\mathrm{nm}$; besides, larger proportions of bacteria, archaea, and fungi, whereas a lower proportion of viruses, were detected. Those significant findings suggested that increasing attention should be paid to the non-negligible health risk resulting from submicron bioaerosols generated from aeration system.

Niazi et al. calculated the bioaerosol concentrations of the largest urban WWTP in the Middle East. According to their findings, the bioaerosol concentration was $1973 \mathrm{CFU} / \mathrm{m}^{3}$ in summer and $1016 \mathrm{CFU} / \mathrm{m}^{3}$ in winter, which greatly affected by aeration tank (Niazi et al. 2015). Moreover, bacteria and fungi made dominating contributions to bioaerosols, which were at hazard levels of bioaerosols. To determine the potential health risks among workers in WWTP, the concentrations and characteristics of bioaerosols generated by the aeration systems should be determined, and the relationships of environmental parameters with bioaerosol generation in the aeration process should also be evaluated.

\section{The treatment sections}

The treatment sections of WWTP cause a wide variety of mechanical motions, and thus significantly exert an influence on the generation of bubble and fine droplet. Karra et al. measured the bioaerosol concentrations during the different treatment sections of urban wastewater treatment plants (Karra and Katsivela 2007). In their study, the air sampler MAS 100 and cultivation methods were employed for air sampling and microorganism detection, respectively. As a result, the highest concentrations of airborne microorganisms were detected at the pretreatment site, where the aerated PM of wastewater was removed. However, the amount of released bioaerosols gradually decreased from pretreatment to primary, secondary, and tertiary treatments during the advanced wastewater treatment process. Such unexpected result might be ascribed to the treatment efficiency and different mechanical motions. Pretreatment possesses had the highest concentration 
microorganism due to their low removal efficiency, which increased the adsorbed content of microorganism in bubble. Grating, grit chamber, and grease interceptor increased the amount of atomized fine droplet because of the intensive mechanical motion.

Species diversity of bioaerosols can be affected by different treatment sections because of the characteristics of wastewater/sludge. For instance, Orbal oxidation ditch (OD) is linked with the aeration part of horizontal rotors and surface turbines, as a result, it can easily generate bioaerosols that contain a variety of microbial pathogens and toxic compositions $(\mathrm{Li}$ et al. 2013). Li et al. employed impaction and polymerase chain reaction (PCR) to monitor the concentrations, size distributions, and species diversity of bioaerosols from WWTP in the OD process ( $\mathrm{Li}$ et al. 2011). As demonstrated by their results, the concentrations of culturable bacteria and fungi in WWTP varied widely, which ranged from $459 \pm 88$ to $5565 \pm$ $571 \mathrm{CFU} / \mathrm{m}^{3}$ and $141 \pm 41$ to $1590 \pm 152 \mathrm{CFU} / \mathrm{m}^{3}$, respectively. Furthermore, the closed sludge dewatering room facilitated to cultivate the highest bacterial concentrations, and fine sand tank cultivated the highest fungi concentrations, indicating the difference of bioaerosols from different sections. Meanwhile, the bioaerosols generated from adjacent treatment section exhibited a closed genetic evolutionary relationship, suggesting the interaction among different treatment sections. Yang et al. assessed the composition characteristics, source allocation, and exposure risk of bioaerosols of WWTP by the OD process, and found the difference of the constitution of bioaerosols in different treatment sections (Yang et al. 2019b). The highest concentrations of bioaerosols and the respiratory fractions $(\mathrm{RF})$ of bacteria were observed in the aeration section of OD. Indoor bioaerosols with the highest non-carcinogenic risk mainly contributed to the sludge treatment processes, such as sludge dehydration chamber (SDR). However, fine grid was the main section with carcinogenic risk. All results suggested that different sections can give rise to specific bioaerosols.

\section{Environmental conditions}

The population structure, concentration distribution characteristics of bioaerosols are affected by the environment (Park et al. 2017). For instance, Pasalari et al. employed the realtime polymerase chain reaction (RT-PCR) technology to determine the concentrations of Rotavirus (RoV) and Norovirus (NoV) discharged from the Ekbatan wastewater treatment plant throughout the year (Pasalari et al. 2019). As suggested by their significant results, the highest concentrations of viruses were detected in winter, whereas the lowest concentrations were observed in summer, and the high loads of two concerned pathogens occurred in autumn season. Therefore, the bioaerosol concentrations were strongly affected by the surrounding temperature among the various meteorological parameters.

Han et al. conducted a 3-year survey on the 9 large WWTPs in different seasons (Han et al. 2020a). Kocuria, Vibrionimonas, and Arcobacter were discriminative across different regions, and the discriminative taxa of fungi in bioaerosols were associated with regions and seasons but not with the processes. Additionally, the release of bioaerosols was positively correlated with environmental conditions, but negatively correlated with the wind speed. Typically, microbial populations of bioaerosols in WWTP are found to show significant regional, seasonal, and process specificities (Heinonen-Tanski et al. 2009). Of them, meteorological factors have greater impacts than chemical composition on the changes of microorganisms in the bioaerosols of wastewater treatment plant.

Michalkiewicz et al. compared the microbial pollutions of air across 11 WWTPs (Michalkiewicz 2018), investigated the effects of air temperature, relative humidity, wind speed, and direction on bioaerosols at each research station, and statistically analyzed the climatic parameters. The results revealed that the highest concentrations of microorganisms ranged from 0 to $1,148,530 \mathrm{CFU} / \mathrm{m}^{3}$ in the wastewater treatment plant area, among which, psychrophilic bacteria (40$\left.225,000 \mathrm{CFU} / \mathrm{m}^{3}\right)$ and mesophilic bacteria $(0-195,000 \mathrm{CFU} /$ $\mathrm{m}^{3}$ ) ranked the first and second places, respectively. Through analyzing the abundances of the interested microorganisms in a specific season, it was determined that the highest median values of most microorganisms (such as mesophilic bacteria, psychrophilic bacteria, Actinobacteria, and fungi) occurred in summer and autumn, whereas the lowest median values (like psychrophilic bacteria and microscopic fungi) were observed in winter. Besides, microscopic fungi were the most closely correlated with air temperature. Among those environmental conditions, temperature was the most tightly related to bioaerosol concentration. Collectively, climatic factors play an indispensable role in varying the concentrations and compositions of bioaerosols.

\section{Conclusions and recommendations}

Inhalable bioaerosols, which harbor various germs, microorganisms, and viruses, have posed a threat to human beings. This paper briefly reviews the bioaerosols generated from toilets and the treatment sections of WWTP, the corresponding generation ways and influencing factors, and other factors involved in health hazard assessment. As discovered from our results, the bioaerosols of toilet are significantly affected by the types of toilets, the energy of flushing, and the surroundings of toilet. Generally, the bioaerosols of WWTP are mainly generated from grating, aerobic pool, and sludge dewatering plant. Consequently, the bioaerosol-related 
airborne infectious diseases may frequently occur when human beings are exposed in such high-risk locations. Through this review, we aim to arouse more concern on the management of bioaerosols and to develop more effective control strategies for the aerosol-induced infections.

Based on the generation, diffusion, and infection processes of bioaerosols, effective strategies may be developed to prevent the transmission of germs, microorganisms, and viruses. The airborne transmission of toilet bioaerosols is associated with multiple factors. First of all, the pathogenic bacteria and viruses should be isolated from the healthy toilet. Reducing the production of germs or viruses in toilet is the primary strategy to control the infection risk of bioaerosols. Besides, separately collecting the feces and vomitus of patients to avoid flowing into the toilet and the pipeline of wastewater helps to reduce the generation of viral bioaerosols. Moreover, isolating the diseased populations by specific toilets may also lower the risk of cross infection with germs from vomitus or feces of patients. Typically, it has been proved that the disinfection of toilet prior to flushing is an effective way that can decrease the bacterial concentrations in the air of the toilet (Zabinski et al. 2018). In addition, wiping the mat and doorknob of toilet with disinfector before use is also important to reduce the contact probability of germs. Moreover, the moving air can dilute the concentrations of bioaerosols, thus maximally decreasing the concentrations of bioaerosols by intensifying the ventilating device. Bacteria and viruses are prone to survive in the wet environment, and dehumidification seems to be an unexpected method for lowering the concentrations of residual bioaerosols on the toilet surface. Finally, cleaning staff should be trained to enhance the effectiveness of disinfection and to lessen the infection risk of individuals.

Bacteria and viruses in wastewater are partly stemmed from the residual bacteria and viruses of toilet and the wastewater system. In the meantime, the bioaerosols of WWTP with complicated population structure and toxicity lead to the occurrence of various infection diseases among the WWTP workers. Weakening the atomization of bacteria and viruses in the wastewater treatment process can greatly reduce the bioaerosol concentrations. Source control can serve as a primary method and is worthy of being advocated. Besides, efforts should be made to reinforce the management of pollutant source, and to control the wastewater containing viruses and germs into municipal pipe. Also, the accident pool should be legitimately utilized to store the hazardous wastewater in the case of an epidemic outbreak. Most WWTP bioaerosols are derived from mechanical agitation; therefore, the wastewater treatment process and parameters of the operating facilities should be optimized, and advanced technologies and machines should be utilized to reduce the occurrence of wastewater interface turbulence, thus lessening the generation of bioaerosols. Inevitable infection usually occurs under the long-term exposure to the air of enriched bioaerosols, so the automation equipment should be intensely used to decrease the exposure duration of sewage workers who are exposed to the surroundings of microbial bioaerosols. Further, a Bayesian belief network model, which can assess the risks under several different scenarios of worker exposure to wastewater and estimate the infection risk in advance, should be developed to decrease the infection risk through occupational exposure to wastewater (Zabinski et al. 2018).

Authors' contributions Ideas: Fang Li; Literature search: Mengmeng Lou, Shuai Liu, Chunjie Gu, and Huimin Hu; Data analysis: Mengmeng Lou, Zhengkun Tang, and Yaopeng Zhang; Writingoriginal draft preparation: Mengmeng Lou; Writing - review and editing: Chenye $\mathrm{Xu}$; Funding acquisition: Fang Li. Critically revised: Fang Li.

Funding This study was supported by the Fundamental Research Funds for the Central Universities (No.20D111328), the Fundamental Research Funds for the Central Universities (No.2232020D-54) and National Key Research and Development Program of China (No. 2016YFC0400501).

Data availability Data sharing is not applicable to this article as no datasets were generated or analyzed during the current study.

\section{Compliance with ethical standards}

Conflict of interest The authors declare that they have no conflict of interest.

Ethical approval and consent to participate Not applicable

Consent for publication Not applicable

\section{References}

Aithinne KAN, Cooper CW, Lynch RA, Johnson DL (2019) Toilet plume aerosol generation rate and environmental contamination following bowl water inoculation with Clostridium difficile spores. Am J Infect Control 47:515-520. https://doi.org/10.1016/j.ajic.2018.11. 009

Amha YM, Anwar MZ, Kumaraswamy R, Henschel A, Ahmad F (2017) Mycobacteria in municipal wastewater treatment and reuse: microbial diversity for screening the occurrence of clinically and environmentally relevant species in arid regions. Environ Sci Technol 51: 3048-3056. https://doi.org/10.1021/acs.est.6b05580

Barker J, Bloomfield SF (2000) Survival of Salmonella in bathrooms and toilets in domestic homes following salmonellosis. J Appl Microbiol 89:137-144. https://doi.org/10.1046/j.1365-2672.2000.01091.x

Barker J, Jones MV (2005) The potential spread of infection caused by aerosol contamination of surfaces after flushing a domestic toilet. J Appl Microbiol 99:339-347. https://doi.org/10.1111/j.1365-2672. 2005.02610.x

Bauer H, Fuerhacker M, Zibuschka F, Schmid H, Puxbaum H (2002) Bacteria and fungi in aerosols generated by two different types of wastewater treatment plants. Water Res 36:3965-3970. https://doi. org/10.1016/S0043-1354(02)00121-5

Benami M, Busgang A, Gillor O, Gross A (2016a) Quantification and risks associated with bacterial aerosols near domestic greywatertreatment systems. Sci Total Environ 562:344-352. https://doi.org/ 10.1016/j.scitotenv.2016.03.200 
Benami M, Gillor O, Gross A (2016b) Potential microbial hazards from graywater reuse and associated matrices: a review. Water Res 106: 183-195. https://doi.org/10.1016/j.watres.2016.09.058

Bennett WD, Scheuch G, Zeman KL, Brown JS, Kim C, Heyder J, Stahlhofen W (1999) Regional deposition and retention of particles in shallow, inhaled boluses: effect of lung volume. J Appl Physiol 86:168-173. https://doi.org/10.1152/jappl.1999.86.1.168

Best EL, Sandoe JAT, Wilcox MH (2012) Potential for aerosolization of Clostridium difficile after flushing toilets: the role of toilet lids in reducing environmental contamination risk. J Hosp Infect 80:1-5. https://doi.org/10.1016/j.jhin.2011.08.010

Bound W, Atkinson R (1966) Bacterial aerosol from water closets: a comparison of two types of pan and two types of cover. Lancet 287:1369-1370. https://doi.org/10.1016/S0140-6736(66)92156-8

Brandi G, Sisti M, Amagliani G (2000) Evaluation of the environmental impact of microbial aerosols generated by wastewater treatment plants utilizing different aeration systems. J Appl Microbiol 88: 845-852. https://doi.org/10.1046/j.1365-2672.2000.01024.x

Carling PC, Bruno-Murtha LA, Griffiths JK (2009) Cruise ship environmental hygiene and the risk of norovirus infection outbreaks: an objective assessment of 56 vessels over 3 years. Clin Infect Dis 49:1312-1317. https://doi.org/10.1086/606058

Caucci S, Karkman A, Cacace D, Rybicki M, Timpel P, Voolaid V, Gurke R, Virta M, Berendonk TU (2016) Seasonality of antibiotic prescriptions for outpatients and resistance genes in sewers and wastewater treatment plant outflow. FEMS Microbiol Ecol 92. https://doi.org/10.1093/femsec/fiw060

Darlow HM, Bale WR (1959) Infective hazards of water-closets. Lancet 1:1196-1200. https://doi.org/10.1016/S0140-6736(59)91201-2

Darquenne C, Brand P, Heyder J, Paiva M (1997) Aerosol dispersion in human lung: comparison between numerical simulations and experiments for bolus tests. J Appl Physiol 83:966-974. https://doi.org/ 10.1152/jappl.1997.83.3.966

Fathi S, Hajizadeh Y, Nikaeen M, Gorbani M (2017) Assessment of microbial aerosol emissions in an urban wastewater treatment plant operated with activated sludge process. Aerobiologia 33:507-515

Fernstrom A, Goldblatt M (2013) Aerobiology and its role in the transmission of infectious diseases. Journal of Pathogens 2013:493960 493913. https://doi.org/10.1155/2013/493960

Fracchia L, Pietronave S, Rinaldi M, Martinotti M (2006) Site-related airborne biological hazard and seasonal variations in two wastewater treatment plants. Water Res 40:1985-1994. https://doi.org/10.1016/ j.watres.2006.03.016

Gerba CP, Wallis C, Melnick JL (1975) Microbiological hazards of household toilets: droplet production and the fate of residual organisms. Appl Microbiol 30:229-237

Giannini MA, Nance D, McCullers JA (2009) Are toilet seats a vector for transmission of methicillin-resistant Staphylococcus aureus? Am J Infect Control 37:505-506. https://doi.org/10.1016/j.ajic.2008.11. 005

Gorny R. (2020) Microbial aerosols: sources, properties, health effects, exposure assessment - a review. Kona Powder and Particle Journal. https://doi.org/10.14356/kona.2020005

Grunwald S, Corstanje R, Weinrich BE, Reddy KR (2006) Spatial patterns of labile forms of phosphorus in a subtropical wetland. J Environ Qual 35:378-389. https://doi.org/10.2134/jeq2005.0042

Haas CN, Rycroft T, Bibby K, Casson L (2017) Risks from ebolavirus discharge from hospitals to sewer workers. Water Environ Res 89: 357-368. https://doi.org/10.2175/106143017X14839994523181

Han Y-P, Yang T, Chen T-Z, Li L, Liu J-X (2019) Characteristics of submicron aerosols produced during aeration in wastewater treatment. Sci Total Environ 696:134019. https://doi.org/10.1016/j. scitotenv.2019.134019

Han Y-P, Yang T, Xu G-S, Li L, Liu J-X (2020a) Characteristics and interactions of bioaerosol microorganisms from wastewater treatment plants. J Hazard Mater 391:122256. https://doi.org/10. 1016/j.jhazmat.2020.122256

Han Y-P, Yang T, Yan X, Li L, Liu J-X (2020b) Effect of aeration mode on aerosol characteristics from the same wastewater treatment plant. Water Res 170:115324. https://doi.org/10.1016/j.watres.2019. 115324

Heinonen-Tanski H, Reponen T, Koivunen J (2009) Airborne enteric coliphages and bacteria in sewage treatment plants. Water Res 43: 2558-2566. https://doi.org/10.1016/j.watres.2009.03.006

Holshue ML, DeBolt C, Lindquist S, Lofy KH, Wiesman J, Bruce H, Spitters C, Ericson K, Wilkerson S, Tural A, Diaz G, Cohn A, Fox L, Patel A, Gerber SI, Kim L, Tong S, Lu X, Lindstrom S, Pallansch MA, Weldon WC, Biggs HM, Uyeki TM, Pillai SK, Washington State 2019-nCoV Case Investigation Team (2020) First Case of 2019 Novel Coronavirus in the United States. N Engl J Med 382: 929-936. https://doi.org/10.1056/NEJMoa2001191

Hsiao T-C, Lin AY-C, Lien W-C, Lin Y-C (2020) Size distribution, biological characteristics and emerging contaminants of aerosols emitted from an urban wastewater treatment plant. J Hazard Mater 388:121809. https://doi.org/10.1016/j.jhazmat.2019.121809

Hutchinson RI (1956) Some observations on the method of spread of Sonne dysentery. Monthly bulletin of the ministry of health and the public health laboratory service $15: 110-118$

Johnson D, Lynch R, Marshall C, Mead K, Hirst D (2013a) Aerosol Generation by Modern Flush Toilets. Aerosol Sci Technol 47: 1047-1057. https://doi.org/10.1080/02786826.2013.814911

Johnson DL, Mead KR, Lynch RA, Hirst DV (2013b) Lifting the lid on toilet plume aerosol: a literature review with suggestions for future research. Am J Infect Control 41:254-258. https://doi.org/10.1016/j. ajic. 2012.04.330

Karra S, Katsivela E (2007) Microorganisms in bioaerosol emissions from wastewater treatment plants during summer at a Mediterranean site. Water Res 41:1355-1365. https://doi.org/10. 1016/j.watres.2006.12.014

Knowlton SD, Boles CL, Perencevich EN, Diekema DJ, Nonnenmann MW, Program CDCE (2018) Bioaerosol concentrations generated from toilet flushing in a hospital-based patient care setting. Antimicrob Resist Infect Control 7:16. https://doi.org/10.1186/ s13756-018-0301-9

Kramer A, Schwebke I, Kampf G (2006) How long do nosocomial pathogens persist on inanimate surfaces? A systematic review. BMC Infect Dis 6:130 http://www.biomedcentral.com/1471-2334/6/130

Lai ACK, Tan T-F, Li W-S, Ip DKM (2018) Emission strength of airborne pathogens during toilet flushing. Indoor Air 28:73-79. https:// doi.org/10.1111/ina.12406

Lange CF, Finlay WH (2006) Liquid atomizing: nebulizing and other methods of producing aerosols. Journal of Aerosol Medicine 19: 28-35. https://doi.org/10.1089/jam.2006.19.28

Li L, Gao M, Liu J-X (2011) Distribution characterization of microbial aerosols emitted from a wastewater treatment plant using the Orbal oxidation ditch process. Process Biochem 46:910-915. https://doi. org/10.1016/j.procbio.2010.12.016

Li Y-P, Zhang H-F, Qiu X-H, Zhang Y-R, Wang H-R (2013) Dispersion and risk assessment of bacterial aerosols emitted from rotating-brush aerator during Summer in a wastewater treatment plant of Xi'an, China. Aerosol Air Qual Res 13:1807-1814. https://doi.org/10. 4209/aaqr.2012.09.0245

Li J, Zhou L-T, Zhang X-Y, Xu C-J, Dong L-M, Yao M-S (2016) Bioaerosol emissions and detection of airborne antibiotic resistance genes from a wastewater treatment plant. Atmos Environ 124:404 412. https://doi.org/10.1016/j.atmosenv.2015.06.030

Li P-Y, Li L, Wang Y-J, Zheng T-L, Liu J-X (2020a) Characterization, factors, and UV reduction of airborne bacteria in a rural wastewater treatment station. Science of The Total Environment :141811. https://doi.org/10.1016/j.scitotenv.2020.141811 
Li Y-Y, Wang J-X, Chen X (2020b) Can a toilet promote virus transmission? From a fluid dynamics perspective. Phys Fluids 32:065107. https://doi.org/10.1063/5.0013318

Lin K, Marr LC (2017) Aerosolization of ebola virus surrogates in wastewater systems. Environ Sci Technol 51:2669-2675. https://doi.org/ 10.1021/acs.est.6b04846

Liu M, Nobu MK, Ren J, Jin X, Hong G, Yao H (2020) Bacterial compositions in inhalable particulate matters from indoor and outdoor wastewater treatment processes. J Hazard Mater 385:121515. https://doi.org/10.1016/j.jhazmat.2019.121515

Lv C, Tsona NT, Du L (2020) Sea spray aerosol formation: results on the role of different parameters and organic concentrations from bubble bursting experiments. Chemosphere 252:126456. https://doi.org/10. 1016/j.chemosphere.2020.126456

Malakootian M, Radhakrishna N, Mazandarany MP, Hossaini H (2013) Bacterial-aerosol emission from wastewater treatment plant. Desalin Water Treat 51:4478-4488. https://doi.org/10.1080/19443994. 2013.769668

Mendes MF, Lynch DJ (1976) A bacteriological survey of washrooms and toilets. J Hyg 76:183-190

Michalkiewicz M (2018) Comparison of wastewater treatment plants based on the emissions of microbiological contaminants. Environ Monit Assess 190:640. https://doi.org/10.1007/s10661-018-7035-2

Mirskaya E, Agranovski I (2018) Sources and mechanisms of bioaerosol generation in occupational environments. Crit Rev Microbiol 44:120. https://doi.org/10.1080/1040841X.2018.1508125

Moazeni M, Nikaeen M, Hadi M, Moghim S, Mouhebat L, Hatamzadeh M, Hassanzadeh A (2017) Estimation of health risks caused by exposure to enteroviruses from agricultural application of wastewater effluents. Water Res 125:104-113. https://doi.org/10.1016/j. watres.2017.08.028

Mohammadi M, Meskini M, do Nascimento Pinto AL (2020) 2019 Novel coronavirus (COVID-19) overview. J Public Health. https://doi.org/ 10.1007/s10389-020-01258-3

Montoya J, Pecha B, Janna FC, Garcia-Perez M (2017) Single particle model for biomass pyrolysis with bubble formation dynamics inside the liquid intermediate and its contribution to aerosol formation by thermal ejection. J Anal Appl Pyrolysis 124:204-218. https://doi. org/10.1016/j.jaap.2017.02.004

Nasir ZA, Campos LC, Christie N, Colbeck I (2016) Airborne biological hazards and urban transport infrastructure: current challenges and future directions. Environ Sci Pollut Res 23:15757-15766. https:// doi.org/10.1007/s11356-016-7064-8

Newsom SW (1972) Microbiology of hospital toilets. Lancet 2:700-703. https://doi.org/10.1016/S0140-6736(72)92102-2

Niazi S, Hassanvand MS, Mahvi AH, Nabizadeh R, Alimohammadi M, Nabavi S, Faridi S, Dehghani A, Hoseini M, Moradi-Joo M, Mokamel A, Kashani H, Yarali N, Yunesian M (2015) Assessment of bioaerosol contamination (bacteria and fungi) in the largest urban wastewater treatment plant in the Middle East. Environ Sci Pollut Res 22:16014-16021

Park JW, Kristanto GA, Rosana FN, Ay Lie H, Hardjasaputra H, Thayaalan P (2017) Analysis of microbial air quality in the surrounding hospital's wastewater treatment plants in Jakarta, Indonesia. MATEC Web of Conferences 138. https://doi.org/10. 1051/matecconf/201713808004

Pasalari H, Ataei-Pirkooh A, Aminikhah M, Jafari AJ, Farzadkia M (2019) Assessment of airborne enteric viruses emitted from wastewater treatment plant: atmospheric dispersion model, quantitative microbial risk assessment, disease burden. Environ Pollut 253: 464-473. https://doi.org/10.1016/j.envpol.2019.07.010

Sanchez-Monedero MA, Aguilar MI, Fenoll R, Roig A (2008) Effect of the aeration system on the levels of airborne microorganisms generated at wastewater treatment plants. Water Res 42:3739-3744. https://doi.org/10.1016/j.watres.2008.06.028

Sassi HP, Reynolds KA, Pepper IL, Gerba CP (2018) Evaluation of hospital-grade disinfectants on viral deposition on surfaces after toilet flushing. Am J Infect Control 46:507-511. https://doi.org/10. 1016/j.ajic.2017.11.005

Uhrbrand K, Schultz AC, Koivisto AJ, Nielsen U, Madsen AM (2017) Assessment of airborne bacteria and noroviruses in air emission from a new highly-advanced hospital wastewater treatment plant. Water Res 112:110-119. https://doi.org/10.1016/j.watres.2017.01. 046

Verani M, Bigazzi R, Carducci A (2014) Viral contamination of aerosol and surfaces through toilet use in health care and other settings. Am J Infect Control 42:758-762. https://doi.org/10.1016/j.ajic.2014.03. 026

Widdowson M-A, Cramer EH, Hadley L, Bresee JS, Beard RS, Bulens SN, Charles M, Chege W, Isakbaeva E, Wright JG, Mintz E, Forney D, Massey J, Glass RI, Monroe SS (2004) Outbreaks of acute gastroenteritis on cruise ships and on land: Identification of a predominant circulating strain of norovirus - united states, 2002. J Infect Dis 190:27-36. https://doi.org/10.1086/420888

Widdowson M-A, Glass R, Monroe S, Beard RS, Bateman JW, Lurie P, Johnson C (2005) Probable transmission of norovirus on an airplane. JAMA 293:1855-1860

Wilson $\mathrm{G}$ et al (2020) Bioaerosols generated from toilet flushing in rooms of patients with Clostridioides difficile infection. Infect Control Hosp Epidemiol 41:1-5. https://doi.org/10.1017/ice.2020.11

Xu H, Yang B, Liu Y-B, Li F, Shen C-S, Ma C-Y, Tian Q, Song X-S, Sand W (2018) Recent advances in anaerobic biological processes for textile printing and dyeing wastewater treatment: a mini-review. World J Microbiol Biotechnol 34:165. https://oi.org/10.1007/ s11274-018-2548-y

Xu J-Y, Chen Y-J, Chen H, Cao B (2020) 2019 novel coronavirus outbreak: a quiz or final exam? Frontiers of Medicine 14:225-228. https://doi.org/10.1007/s11684-020-0753-1

Yang K-X, Li L, Wang Y-J, Xue S, Han Y-P, Liu JX (2019a) Airborne bacteria in a wastewater treatment plant: emission characterization, source analysis and health risk assessment. Water Res 149:596-606. https://doi.org/10.1016/j.watres.2018.11.027

Yang T, Han Y-P, Liu J-X, Li L (2019b) Aerosols from a wastewater treatment plant using oxidation ditch process: characteristics, source apportionment, and exposure risks. Environ Pollut 250:627-638. https://doi.org/10.1016/j.envpol.2019.04.071

Zabinski JW, Pieper KJ, Gibson JM (2018) A bayesian belief network model assessing the risk to wastewater workers of contracting ebola virus disease during an outbreak. Risk Anal 38:376-391. https://doi. org/10.1111/risa.12827

Zhang X-W, Hu Z, Ngo HH, Zhang J, Guo W-S, Liang S, Xie H-J (2018) Simultaneous improvement of waste gas purification and nitrogen removal using a novel aerated vertical flow constructed wetland. Water Res 130:79-87. https://doi.org/10.1016/j.watres.2017.11.061

Publisher's note Springer Nature remains neutral with regard to jurisdictional claims in published maps and institutional affiliations. 